\title{
Legal Protection To The Indonesian Migrant Workers In The Perspective Of Human Rights
}

\author{
Raden Muhammad Mihradi \\ Law Faculty, Universitas Pakuan, \\ Bogor, Indonesia
}

\begin{abstract}
Purpose of the study: This research aims to describe legal issue related to the protection to Indonesian migrant workers who work abroad and to analyze the existence of migrant workers in Indonesia, viewed from human rights which must get legal protection in constitution and regulation of legal norm and implementation in the applicable legislation. Methodology: This research used the normative research methodology supported by empirical data from the document of institutional study. Main Findings: Research about the protection of human rights in Indonesian Migrant Worker sector is a certainty. It is guaranteed in the international documents (Declaration of Human Rights in the United Nations, Convention of United Nations on Ecosoc and ILO Convention) and national documents (1945 Constitution and Law of Indonesian Migrant Worker Protection). However, in the perspective of its implementation, it has complexity. The protection to Indonesian migrant workers involves many parties, central and regional rules, and culture. This research focuses on the context of Indonesian Migrant Worker protection in a country where they work from the perspective of human rights. This research has novelty since it captures and analyzes issue of Indonesian Migrant Worker in rules and empirical terms based on the database. Applications of this study: this study can be useful for Immigration is one of the instruments to support unity of family with different nationality background. Novelty/Originality of this study: The new in this study that may find the ideal concept of the treasury of jurisprudence, particularly for foreign citizens who legally get married with Indonesian citizens and ex-Indonesian citizens and children born from legitimate mixed marriage with double citizenship.
\end{abstract}

Keywords: Mixed Marriage, Inheritance, Dual Citizenship. International Civil Law

\section{INTRODUCTION}

Issue of migrant worker is faced by Indonesia on a regular basis every year. The causes are predictable, poverty and unemployment. It is almost certain that no citizens want to be unemployed since the beginning. The state should guarantee the absence of unemployment. In fact, state should not be completely able to provide proper work opportunity. Based on the data of Central Bureau of Statistics per February 2018, it shows that around 7.64 percent of 127.07 million people worked in the category of underemployed, while 23,83 percent of them are part-time workers. Such condition encourages the citizens to work abroad as one of the choices which may be taken to improve the standard of living.

Indonesian migrant worker is often called "the hero of foreign exchange". Throughout 2019, Bank Indonesia recorded the remittance by migrant worker of USD 2.9 billion or equal to IDR 40.8 trillion. Such money was transferred by 3.7 million of Indonesian migrant workers in tens of states worldwide in which most of them work in informal sector. Meanwhile, until second quarter of 2019, Bank Indonesia recorded 3.7 millions of Indonesian migrant workers abroad. This amount increased by 0.9 percent, compared with previous quarter. Meanwhile, 51.4 percent of workers earned a living in Malaysia and 25.7 percent of them were in Saudi Arabia. 
However, not all Indonesian migrant workers are providential in the country where they work, since many workers experience violence which leads to death.

https://www.cnnindonesia.com/tag/nttBoard for Placement and Protection of Indonesian Overseas Workers in East Nusa Tenggara received 73 dead bodies of Indonesian migrant workers from January to August 2019 as a result of violence experienced in the country where they work. Furthermore, there were other Indonesian migrant workers who work illegally. In Malaysia, from June 29, 2009 to March 2012, Indonesia performed moratorium to send Indonesian migrant workers, particularly in informal sector (housemaid). After moratorium, from July to September 2012, Indonesian government only positioned 64 housemaids from Indonesia to Malaysia. However, the fact states that around 14,000 work permits and job performance visa were also issued by government of Malaysia (Hidayah, 2019). It means that they entered Malaysia illegally, without being noticed by Indonesian government, while they were not officially sent to Malaysia but they got legality in Malaysia. Implication of nonprocedural or illegal Indonesian migrant workers is very serious. They are vulnerable to issues in country where they are placed, such as the absence of legal protection, being vulnerable to experience violence, unpaid wage, and other tragic issues which lead to death. Such condition occurs because it is difficult for the state to monitor the existence of Indonesian migrant workers.

It can be confirmed that Indonesian migrant workers obviously have human rights. All international and national documents require the assurance of issues about human rights and Indonesian migrant workers, starting from Universal Declaration of Human Rights in United Nations, Convention of United Nations concerning Migrant Workers to provision in Article 27 of 1945 Constitution. None of these documents provide affirmation to the infringement of human rights to Indonesian migrant workers. It also applies in the operational level through the issuance of Law No. 18 Year 2017 concerning Protection to the Indonesian Migrant Workers. These legal documents specifically mandate that Indonesian migrant workers should be protected from human trafficking, slavery, forced labour, violence, arbitrariness, and several treatments which infringe human rights. Issues are regulation, institution, and culture which are not yet completely friendly to the human right protection for Indonesian migrant workers.

Based on the aforementioned analysis, legal issue of migrant workers becomes an interesting topic to be analyzed with two problem formulations, namely (1) why do migrant workers abroad get less legal protection? and (2) how is the perspective of human rights concerning the legal protection in the norms as regulated in law?

\section{LITERATURE REVIEW}

In conceptual-historical terms, about the history of human rights struggle from several documents, it is identified that history has been started from Magna Carta Charter in 1215 in Britain. However, Scott Davidson stated that Magna Carta is only 'compromise of power sharing between King John and his noblemen'. Movement of human right protection which is more comprehensive is actually in the Bill of Rights in 1689. It is the struggle of parliament against the kings from Stuart who acted arbitrarily in 17th century. This struggle is an inspiration which encouraged Declaration of Independence in the United States of America in 1776 and Declaration of Human Rights and Citizens in France in 1789. These declarations leaded to Universal Declaration of Human Rights in United Nations on December 10, 1948 (Davidson, 1994).

Related to human rights of migrant worker, in terminology of human rights itself, they are economic, social, and cultural rights. It is guaranteed in International Covenant on Economic, 
Social and Cultural Rights (ECOSOC) as ratified in Indonesia with Law No. 11 Year 2005. Ecosoc right in this context encourages assurance of proper occupational right. Theoretically, formulation of Ecosoc Right is from tradition of Saint-Simonians in the beginning of 19th century in France as criticism to the capitalism development which exploits worker class. Character of Ecosoc Right is positive right family. It means that the fulfilment of that right encourages contribution from the state. State obligation to meet the right must be stipulated in the constitution, so it can bind all parties, state, and citizen. It is reflected in Article 27 verse (2) of 1945 Constitution which states that: "Every citizen shall have the right to work and to earn a humane livelihood" (Mihradi, 2017).

Operationalization in human rights from migrant worker is regulated in Law No. 18 Year 2017 concerning Protection to Indonesian Migrant Workers. Law of Protection to Indonesian Migrant Workers revokes Law No. 39 Year 2004 concerning Placement and Protection to Indonesian Migrant Workers Abroad. There are three reasons to replace Law of Placement and Protection to Indonesian Migrant Workers Abroad with Law of Protection to Indonesian Migrant Workers. First, there is mistake in philosophical paradigm in Law of Placement and Protection to Indonesian Migrant Workers Abroad which views migrant worker as commodity. It is not the subject which needs to be protected and empowered. The consequence is very serious because they work in capitalist economic logic in which labourers are only production factor. Neglect to worker rights is certainty for efficiency. Second, there is no article in Law of Placement and Protection to Indonesian Migrant Workers Abroad oriented to human right protection. It is affirmation in several practices which harm dignity of migrant workers. Third, regulation of agent role to direct migrant worker is dominant. It turns out that government has limited authority. As the result, protection to migrant worker is weak because of infringement by the agent of migrant worker as efficiency manifestation in business (Mihradi, 2017).

It is deconstructed by Law of Protection to Indonesian Migrant Workers. Improvement of human right regulation dominates articles in Law of Protection to Indonesian Migrant Workers. Role of country, central and regional government is improved. Dignity of migrant worker is respected. Improvement to the rights of migrant worker is regulated, such as in Article 6 verse (1) of Law of Protection to Indonesian Migrant Workers; Indonesian migrant workers have right to access self-capacity improvement through education and work training, obtain the right information concerning work market, placement procedure, and occupational condition abroad, worship, and get wage based on standard, and so on. Moreover, some rights are not known in Law of Placement and Protection to Indonesian Migrant Workers Abroad, particularly the right for every family of migrant worker. Article 6 verse (3) in Law of Protection to Indonesian Migrant Workers states that every family member of migrant workers shall be entitled to get information about condition, issue, and homecoming of Indonesian migrant workers, get copy of document and employment agreement of candidate of Indonesian migrant workers and/or Indonesian migrant workers, and so on.

Protection to Indonesian migrant workers is divided into protection before work, protection while working, and protection after work (Article 7 of Law of Protection to Indonesian Migrant Workers). Similarly, to be placed in destination country, candidates of Indonesian migrant workers shall have documents, such as statement of marital status, statement of permit from husband or wife, permit from parent, permit from guardian, as known by village head or headman, work competence certificate, certificate of able-bodied, and so on (Article 13 of Law of Protection to Indonesian Migrant Workers). Besides, the state regulates pattern in the context of ensuring legal protection in which Indonesian migrant workers can only work in destination country which meets requirements as follows: (a) having legislation which protects foreign labour; (b) owning written agreement between government in destination country and 
government of the Republic of Indonesia; and/or (c) having social security system and/or insurance which protects foreign workers (Article 31 of Law of Protection to Indonesian Migrant Workers).

Meanwhile, in institution, it regulates an integrated service of placement and protection to Indonesian migrant workers, task and responsibility of central government, and government of province, regency/city to village (Article 38 - Article 43 of Law of Protection to Indonesian Migrant Workers). Besides ministry, it establishes an agency to protect Indonesian migrant workers as regulated in Article 46 and Article 47 of Law of Protection to Indonesian Migrant Workers.

Related to the placement of Indonesian migrant workers, in Law of Placement and Protection to Indonesian Migrant Workers Abroad, the role is limited. In Law of Placement and Protection to Indonesian Migrant Workers Abroad, the agent for placement of Indonesian migrant workers has role before, at the time of, and after placement, but it is limited in Law of Protection to Indonesian Migrant Workers. In Law of Protection to Indonesian Migrant Workers, the agent is Company for Indonesian migrant workers assignment in which its task and responsibility are limited to: (a) searching work opportunity; (b) assigning Indonesian migrant workers and, (c) settling issue of Indonesian migrant workers who are assigned (Article 52 of Law of Protection to Indonesian Migrant Workers). Company for Indonesian migrant workers assignment must have permit from Minister, in form of Permit For Indonesian Migrant Worker Placement Company and Permit for Indonesian Migrant Work Recruitment. These two permits have specific requirements as intended to protect Indonesian migrant workers. In order to get Permit for Indonesian Migrant Work Recruitment, company for Indonesian migrant workers placement must have documents as follows: (a) Cooperation Agreement for Placement; (b) request letter of Indonesian migrant workers from the employer; (c) draft placement agreement, and (d) draft employment agreement (Article 59 verse (4) of Law of Protection to Indonesian Migrant Workers).

Besides, concerning criminal sanction, there is provision which can impose sanction to company, officials, and individuals who infringe the Law of Protection to Indonesian Migrant Workers, up to imprisonment of 10 years and fine of IDR 15 billion (e.g., Article 83 in Law of Protection to Indonesian Migrant Workers). Meanwhile, punishment is imposed to the officials as regulated in Article 84 of Law of Protection to Indonesian Migrant Workers

\section{METHODOLOGY}

This research used normative juridical research methodology by studying legislation (law in book) and making use of the limited empirical data. Approach used was statute approach to the legal material, namely Law No. 18 Year 2017 concerning Protection to Indonesian Migrant Worker. Besides, with conceptual approach by understanding the thought of legal norm in Law, analysis was conducted qualitatively and described.

\section{Condition of Migrant Worker}

\section{DISCUSSION/ANALYSIS}

When identified, issues of Indonesian migrant workers in general are constantly repeated. First issue is illegal Indonesian migrant workers. In Malaysia, in 2016, many Indonesian migrant workers were found to enter Malaysia in an illegal way, through land and sea. Borders, such as Sabang-Aceh and Nunukan-East Kalimantan are often the illegal entrances. It occurred until 2019. Meanwhile, in Hong Kong, the same case occurred in 2016, in which overstayer made Indonesian migrant workers illegal. However, Hong Kong is more flexible to provide 
opportunity to Indonesian migrant workers who are overstayer to make proposal and are allowed to stay in Hong Kong.

In Malaysia, amount of illegal Indonesian migrant workers is the largest. Embassy of the Republic of Indonesia in Malaysia recorded that almost 50 percent of Indonesian migrant workers working in Malaysia are illegal from 5 (five) million Indonesian workers in Malaysia. Besides, policy from the government of Malaysia limits illegal workers. Almost every year, government of Malaysia issues policy to the foreign labours working in Malaysia starting from policy of 6 P (in 2011-2014), rehiring policy (2015-2016), $3+1$ (2015-2017) and rehiring with E-Kad (2017). Rehiring program with E-Kad has been launched since 2016 after the meeting between Embassy of the Republic of Indonesia and stakeholder in Malaysia, government of Malaysia in particular. E-Kad is temporary permit card for foreign labours who do not have document and it was applied from February 2017 to February 15, 2018. Indonesian migrant workers with E-Kad are obliged to get official permit to be legal for working in Malaysia. Until 2019 , these several policies do not solve issue of illegal Indonesian migrant workers.

Second issue, Indonesian migrant workers have minimum competence. As the result of Regional Representative Council of the Republic of Indonesia to Malaysia, South Korea, and Hong Kong in 2016, Indonesian migrant workers lack of competence. Low competence does not only refer to occupational skill, but also capability in using local language, including adaptation to local culture. Implication is that wage received is much lower than migrant workers from other countries with competence. The issue is that competence improvement frequently faces obstacles, such as limitation of Vocational Training Centre. In West Nusa Tenggara Province, until 2016, it only has one VTC, Lombok Mandiri. It is owned by private company and there is no Competence Test and certification test, so it needs to refer to the centre. In March 2019, West Nusa Tenggara province has Vocational Training Centre abroad which is officially owned by government of province and based on requirement of Indonesian migrant workers. In 2018, VTC of new community has been established by government in which 75 VTCs are for improving competence in the candidate of Indonesian migrant workers. It is for responding issue of competence.

Third issue is anticipation of problematic Indonesian migrant workers in destination country. National Agency for Placement and Protection to Indonesian Migrant Workers in the report of recapitulation complaint in 2018, there are 10 largest complaints from Indonesian migrant workers to destination country as follows:

1. 441 complaints about Indonesian migrant workers without documents

2. 332 complaints about Indonesian migrant workers who want to return to home country

3. 228 complaints about unpaid wage

4. 226 complaints about Indonesian migrant workers who were failed to depart

5. 175 complaints about sick Indonesian migrant workers

6. 107 complaints about lost contact

7. 65 complaints about excessive salary cut

8. 59 complaints about work which is not suitable

9. 59 complaints about imprisoned Indonesian migrant workers

10. 56 complaints about termination of employment before contract

\section{Rule Improvement}

Based on the data above, top three issues of Indonesian migrant workers are absence of document; desire to return to home country, and unpaid wage. For the case of document, it does not completely reflect the condition; in Malaysia, undocumented data are much larger 
than official data. Management of 10 complaints above must be comprehensive. According to the researcher, some solutions are as follows:

a. Considering that Law of Protection to Indonesian Migrant Workers has been ratified, it is urgent to issue several derivate legislations. For the region, it needs to issue regional regulations considering that Law of Protection to Indonesian Migrant Workers in local government needs to improve authority. Some regions have initiated them, such as Lampung, to issue Local Regulation No. 16 Year 2014 concerning Placement and Protection of Indonesian Migrant Workers in Lampung Province Abroad, to be revised adjusted to Law of Protection to Indonesian Migrant Workers. Government of City and Malang Regency has similar draft of Local Regulation to respond them.

b. Besides, regulation in centre and region needs to ensure legal enforcement. In theory of law enforcement, besides its legal factor, law enforcer, supporting facilities, society, and culture affect the law enforcement (Soekanto, 2016). It is difficult to deny that in policy of Indonesian migrant workers, factors besides rule are weak. For example, officials who do not carry out their task properly. Limitation of facilities and infrastructure for training to the candidate of Indonesian migrant workers. There is a culture which only views from one aspect to be Indonesian migrant workers, to have proper income. Meanwhile, the risk of working abroad is not considered.

c. There is dilemma from the perspective of human rights related to Indonesian migrant workers. On the other hand, Indonesian migrant workers from Indonesia work in labour/housemaid sector. Thus, there is requirement in destination country concerning regulation about worker or housemaid to protect Indonesian migrant workers. However, Draft Law concerning Housemaid has not been ratified and it has been almost 10 years since the National Legislation Program in 2010. However, there is ILO Convention No. 198 Year 2011 concerning Proper Occupation for Housemaid. Thus, in the perspective of human rights, it is impossible to protect human rights when there is no feedback in ensuring the same thing in the context of Indonesian migrant workers.

d. In the paradigm of human rights, it requires norm institution and socialization to the public. It is a limitation considering that many candidates and Indonesian migrant workers do not understand requirement and procedure which are valid to work abroad. They do not understand their right and obligation. Country is not optimal in socializing this issue to public.

\section{Legal Compliance Process}

In legal theory, rule improvement for protecting law of migrant worker is to interpret the law itself as an improvement process (Huijbers, 1982; Tanya, 2010). In the beginning, it is stated by Maurice Hauriou that human beings do not want to obey the reality development. Life experience makes them realize and have desire to obey rule. Support from other parties to live together, particularly in state institution, improves way of life to obey rule. State institution is a place for citizens to condition people for obeying law.

Legal compliance process is an important part when migrant workers are given legal protection by the state. Compliance to law is not established automatically. Socialization of norms in Law No. 18 Year 2017 for the migrant worker is absolute to be implemented when legal obedience is required by the state. Maurice Theory is important in the context of living together as performed by migrant worker living outside Indonesia. Migrant workers must be conditioned to the state with conducive supervision.

Creation of integrated system between central and regional government and society in general elucidation of Law No. 18 Year 2017, in the analysis of researchers to provide meaning to legal obedience for migrant worker abroad, must be implemented. Since the authority of 
government is intended for maintaining coexistence. Therefore, perspective of human rights for migrant worker is in line with theory of Maurice in the context of legal obedience.

\section{CONCLUSIONS}

From the aforementioned analysis, it can be concluded that issuance of Law No. 18 Year 2017 concerning Protection to the Indonesian Migrant Workers (Law of Protection to Indonesian Migrant Workers) has brought new paradigm that Indonesian migrant workers must be viewed as subject with human rights to be obliged by state. Second, after the issuance of Law of Protection to Indonesian Migrant Workers, it should be immediately followed by several legislations for operationalization, including several Regional Regulations which must have the same spirit and dimension to protect and empower Indonesian migrant workers.

Issue to the protection for Indonesian migrant workers does not relate to rule norms which provide justice to Indonesian migrant workers, but implementation of its legal enforcement must be consistent. Some individuals who harm Indonesian migrant workers must be immediately punished, so law remains reference in managing existence and sustainability of Indonesian migrant workers. Support in form of facilities and infrastructure is important part which cannot be denied to be immediately prepared by government to support Indonesian migrant workers to be better and human right protection as objective for common goodness.

\section{LIMITATION AND STUDY FORWARD}

Researchers realize that the results of this study are not yet perfect, so it is necessary to be continued by subsequent researchers to enrich the treasury of jurisprudence, particularly for concerning protection Indonesian migrant workers as subject with human rights to be obliged by state.

\section{ACKNOWLEDGEMENT}

The researchers would like to thank the Chancellor of Jayabaya University for providing the research with the title: "Legal Protection To The Indonesian Migrant Workers In The Perspective Of Human Rights".

\section{References}

Tanya, Bernard L. (2010) Teori Hukum, Yogyakarta: Genta Publishing.

Davidson, Scott, (1994) Hak Asasi Manusia: Sejarah, Teori, dan Praktik Dalam Pergaulan Internasional, (terjemahan), Jakarta: Pustaka Utama Grafiti.

Hidayah, Anis, (2019) Di Balik Remitansi: Realitas Pelanggaran HAM Terhadap Buruh Migran Indonesia, Jakarta: Kepustakaan Populer Gramedia.

Huijbers, Theo, (1982) Filsafat Hukum Dalam Lintasan Sejarah, Yogyakarta: Pustaka Filsafat, Kanisius.

Mihradi, Raden Muhammad (2017) Meneroka Relasi Hukum, Negara dan Budaya, Jakarta: Yayasan Pustaka Obor Indonesia.

Soekanto, Soerjono, (2016) Faktor-Faktor Yang Mempengaruhi Penegakan Hukum, Jakarta: Rajawali Pers.

1945 Constitution of the State of the Republic of Indonesia.

Law No. 18 Year 2017 concerning Protection for Indonesian Migrant Worker.

Law No. 39 Year 2004 concerning Placement and Protection to Indonesian Migrant Workers Abroad.

Law No. 11 Year 2005 concerning Ratification of International Covenant On Economic, Social And Cultural Rights

Regional Regulations of Lampung Province Government No. 16 Year 2014 concerning Placement and Protection to Indonesian Migrant Workers in Lampung Province Abroad.

Manuscript of Convention concerning Proper Occupation for Housemaid, Conference of International Labour, No. 198 Year 2011. 
Supervision Report of Regional Representative Council of the Republic of Indonesia on Implementation of Law No. 39 Year 2004 concerning Placement and Protection to Indonesian Labours Abroad, Year 2016.

Work Visit Report Committee III of the Regional Representative Council of the Republic of Indonesia in Supervising Implementation of Law No. 39 Year 2004 concerning Placement and Protection of Indonesian migrant workers Abroad dated February 2 - March 2, 2016.

Report of Urgent Visit for Head of Regional Representative Council of the Republic of Indonesia in Inventory and Aspiration for Settlement of Illegal Indonesian Migrant Workers and E-Kad Program in Malaysia, dated 14-17 July 2017.

Report of Supervision from Regional House of Representative, Republic of Indonesia, on the Implementation of Law No. 18 Year 2017 concerning Protection to Indonesian Migrant Worker Year 2018.

https://bisnis.tempo.co/read/1234306/triwulan-ii-2019-bi-rp-40-t-uang-tki-pulang-ke-tanah-air. https://bisnis.tempo.co/read/1234306/triwulan-ii-2019-bi-rp-40-t-uang-tki-pulang-ke-tanah-air. https://www.cnnindonesia.com/nasional/20190904105135-20-427382/januari-agustus-73-pekerja-migran-nttyang-tewas-dipulangkan.

http://infopublik.id/kategori/nusantara/335788/provinsi-ntb-resmi-miliki-blk-luar-negeri?show.

https://nasional.kontan.co.id/news/kemnaker-targetkan-bangun-1000-blk-baru-di-2019-untuk-tekanpengangguran.

https://databoks.katadata.co.id/datapublish/2019/07/30/inilah-10-pengaduan-terbesar-terkait-penempatanpekerja-migran-indonesia 